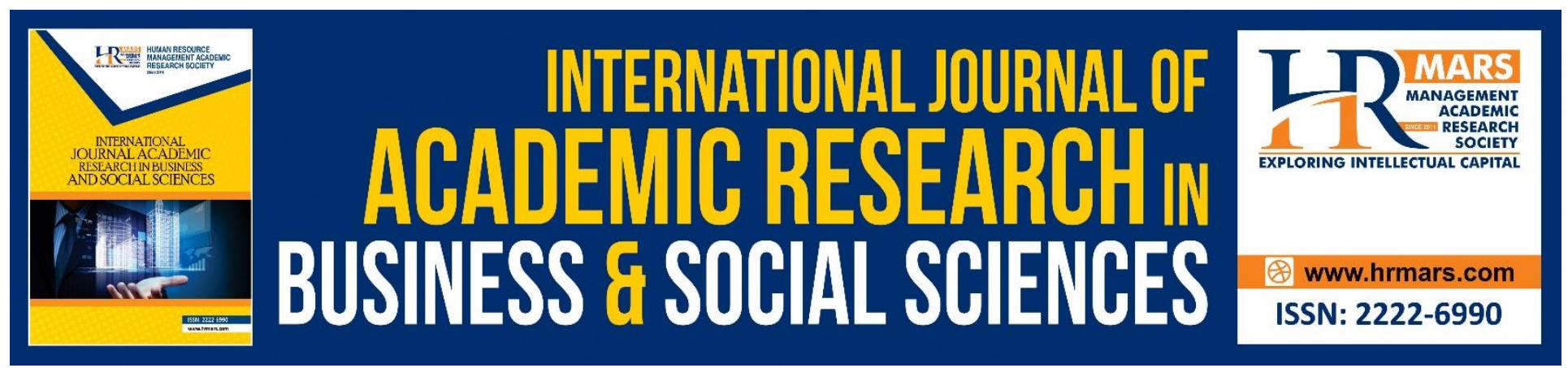

\title{
Effect of E-Service Quality on the Intention to Reuse Website of Ota in Buying Aircraft Tickets
}

Bagja Waluya, Oce Ridwanudin, Wanda Dania Utami

To Link this Article: http://dx.doi.org/10.6007/IJARBSS/v9-i3/5745 DOI: $10.6007 /$ IJARBSS/v9-i3/5745

Received: 29 Jan 2019, Revised: 23 Feb 2019, Accepted: 10 March 2019

Published Online: 27 March 2019

In-Text Citation: (Waluya, Ridwanudin, \& Utami, 2019)

To Cite this Article: Waluya, B., Ridwanudin, O., \& Utami, W. D. (2019). Effect of E-Service Quality on the Intention to Reuse Website of Ota in Buying Aircraft Tickets. International Journal of Academic Research in Business and Social Sciences, 9(3), 789-799.

Copyright: (C) 2019 The Author(s)

Published by Human Resource Management Academic Research Society (www.hrmars.com)

This article is published under the Creative Commons Attribution (CC BY 4.0) license. Anyone may reproduce, distribute, translate and create derivative works of this article (for both commercial and non-commercial purposes), subject to full attribution to the original publication and authors. The full terms of this license may be seen

at: http://creativecommons.org/licences/by/4.0/legalcode

Vol. 9, No. 3, 2019, Pg. 789 - 799

http://hrmars.com/index.php/pages/detail/IJARBSS

JOURNAL HOMEPAGE

Full Terms \& Conditions of access and use can be found at http://hrmars.com/index.php/pages/detail/publication-ethics 


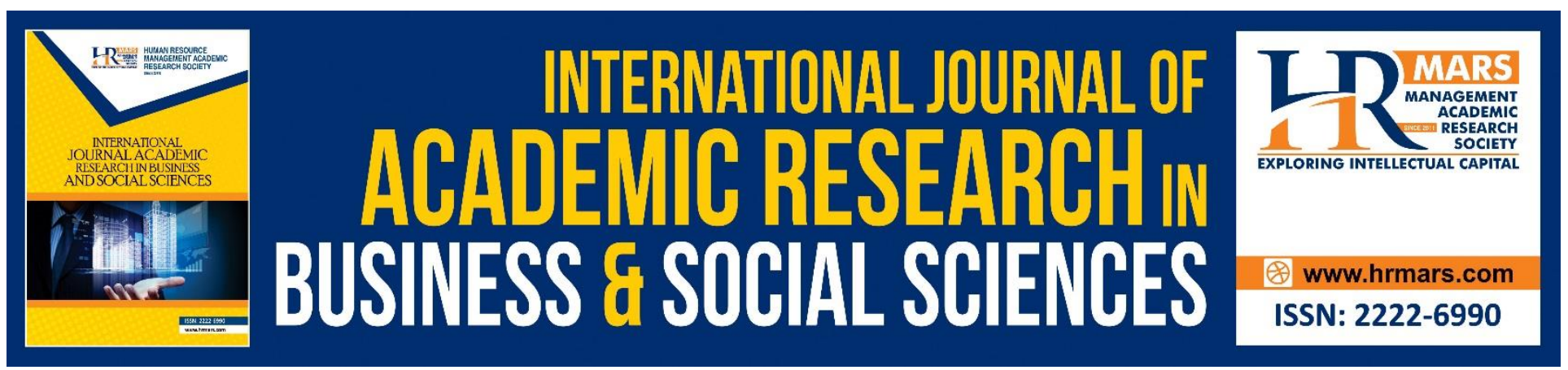

\title{
Effect of E-Service Quality on the Intention to Reuse Website of Ota in Buying Aircraft Tickets
}

\author{
Bagja Waluya, Oce Ridwanudin, Wanda Dania Utami \\ Universitas Pendidikan Indonesia, Indonesia
}

\begin{abstract}
The intention to reuse the e-commerce website on the air ticket booking website proves that users who are used to purchasing online services are less satisfied and have low intention to reuse the website. This study aims to determine the picture of e-service quality on intention to reuse on students of Traveloka Users, Tiket.com Users and Booking.com Users at Faculty of Social Sciences Education University of Indonesia Bandung. Independent variable in this research is e-service quality $(X)$ to dependent variable $(Y)$ that is intention to reuse. The type of research used is descriptive and verifikatif with the method used explanatory survey and cross sectional method approach. Samples in this study as many as 300 FPIPS UPI students include 129 respondents Traveloka users, 99 respondents Tiket.com users and 72 respondents Booking.com users. With sampling technique that is sample random sampling and to get a proportional sample, then used technique Proportionate Stratified Random Sampling, analysis technique used is multiple regression and independent sample T-Test to know the difference in each object. Feedback of FPIPS students UPI of Traveloka, Tiket.com and Booking.com users to high intention to reuse, personalization dimension, reliability and fulfillment have a significant influence while the availability and security dimension has no significant effect.
\end{abstract}

Keywords: E Servive Quality, Intention to reuse, Traveloka

\section{Introduction}

The development of the use of internet providers of data search services or information and communication tools, encourages the potential of creating an intention to reuse. Researching the intention to reuse an e-commerce website on an airline ticket booking website proves that users who are accustomed to purchasing online services are less satisfied and have a low intention to reuse to reuse the website (Madlberger \& Matook, 2017). So studying the antecedents of intention to reuse is an important issue for researchers to develop e-commerce information systems (Sun \& Ju, 2005) especially on websites airline ticket booking.

Data collected from the Ministry of Tourism shows that the tourism business in Indonesia in 2016 experienced a growth of $1.97 \%$ compared to 2015 . The progress and development of the business world is in tandem with technological developments. The form of business that is influenced by this 
technology is e-commerce (Putri \& Susanta, n.d.). The rapid development of Indonesian tourism raises the ease of tourism transactions through online travel agents (OTA).

To be able to become a superior OTA must be able to increase the willingness of consumers to buy back/intention to reuse. Consumers are very easily facilitated by online flight ticket and hotel sales sites because it is very effective. Usually, consumers search information before ordering flight tickets on an online site. The following data channel overview serves to determine consumer behavior in using Traveloka compared to competitors, namely Tiket.com and Booking.com.

The impact of high consumers who do not want to reuse a website affects the profitability and value of the company (Madlberger \& Matook, 2017). The value given by the company in a website becomes the crucial point for the customer to do online transaction. It can also influence the user to reuse a website (Adapa \& Ray, 2013; Lim, 2014). The low intention to reuse can occur because it is dominated by dissatisfaction, leading to negative word of mouth which reduces the customer's intention to use reset. The impact is that online travel agents can experience losses and create poor brand image. In a long-term, it causes the lack of intention to reuse, and as a result bankruptcy might occur.

Repurchase intention (intention to reuse) is basically a consumer behavior where they respond positively to a company's e-service quality and intend to make a sustainable repurchase $(\mathrm{Wu}, \mathrm{Wu}, \&$ $\mathrm{Pu}, 2016)$. Traveloka, Tiket.com and Booking.com are companies engaged in aircraft ticket booking services focusing on e-service quality by paying attention to dimensions that can shape perceived eservice quality through availability, security, personalization, reliability and fulfillment dimensions. (Asadpoor \& Abolfazli, 2017) who are expected to increase their intention to reuse. Our findings contribute to the tourism marketing literature by providing an understanding of e-service quality and intention to reuse on OTA website.

The objective of the study are as follow:

i. To get the description of the intention to reuse on Traveloka, Tiket.com and Booking.com online travel agents

ii. To get the description of e-service quality on Traveloka's online travel agent, Tiket.com and Booking.com ,

iii. To find out the effect of e-service quality on the intention to reuse on Traveloka's online travel agent, Tiket.com and Booking.com

\section{Literature Review}

A. E-Service Quality in Marketing Management

Marketing is the activity and process of creating, communicating, conveying, and exchanging something that has value for consumers, clients, partners, and the general public (American Marketing Association, n.). Marketing is about identifying and uniting between human and social needs (Kotler \& Keller, 2016).

New marketing behavior, opportunities, and challenges that arise due to technology, globalization, and social responsibility. The pace of change and the scale of technological achievement is very surprising. City residents are able to access the internet every month. With the rapid growth of ecommerce, mobile Internet and Web penetration in emerging markets (Kotler \& Keller, 2016).

Service quality in the online environment is the determination of the success or failure of electronic commerce. One of the most widely used models is the eServqual model (Akbar \& Djatmiko, 2016). A 
company in increasing customer satisfaction does not create enough quality products, but the company must also maintain the quality of service to always create customer convenience in shopping. Service quality in e-commerce is called e-service quality (Sativa, Rahayu, \& Astuti, 2016). In the context of tourism, (Lee \& Lin, 2005) developed a quality scale of E-travel services.

B. E-Service Quality

E-service quality is defined as "the extent to which a website facilitates shopping, purchasing and shipping products and services effectively and efficiently" (Laurent, 2016).

There are five dimensions of e-service quality according (Adapa \& Ray, 2013) that is:

a. Availability means completeness or how available the online site is.

b. Security is freedom from danger, risk, or doubt. This gives rise to the convenience of customers to exchange information and conduct financial transactions online in response to positive expectations of consumers regarding online company behavior.

c. Personalization involves individual or personal attention, thanks from online stores, and availability of places to ask questions or comments for customers.

d. Reliability includes consistency in performance and reliability. That means that the company will perform services in the right way, maintain records accurately and also ensure the security of personal information.

e. Fulfillment means the accuracy of service appointments, product delivery within the promised time.

C. Intention to reuse

Intention to reuse online is a situation when a customer is willing and intends to engage in a transaction in the future (Yoon, n.d.). The experience of customers with the Internet encourages the growth of internet shopping. Customers with a strong online intention to reuse usually have a previous purchasing experience that helps in reducing their uncertainty (Adiwibowo, Widodo, \& Santosa, 2015). Therefore, customers will only buy products from the internet after they feel positive about the transaction.

D. Thinking Framework

With the rapid growth of e-commerce, mobile Internet and Web penetration in emerging markets (Kotler \& Keller, 2016). Ecommerce includes electronic fund transfers, exchanges and data collection. Components in e-commerce transform from the classic marketing mix, or the "7P" concept, offered in 1981 by people Amerikailmuwan: B.H. Booms \& M.J Bitner (1981) in the e-commerce environment (Pogorelova, Yakhneeva, \& Anna, 2016)) which consists of product, price, place, promotion, people, process and physical evidence.

The promotion of marketing communication mix is online \& social media marketing in the form of websites (Kotler \& Keller, 2016). The new service quality especially in the world of e-commerce is the quality of web-based services. E-ServQual was developed to evaluate a service provided on an Internet network. E-service quality that has been recognized as an important concept in destination marketing and the importance of measuring intention to reuse to measure the success of an online travel agent. 
E. Hypothesis

1. Yoon (n.d.) produces customer satisfaction and perceived value by using quality web sites (eservice quality). An empirical study found that the quality of a website is positively related to the perceived value of the customer / intention to reuse.

2. Chun \& Kwak (2016) states the results of the analysis show that the quality factors in the website (e-service quality) have a significant impact on the intention to reuse users; ease of use and interest. Reliability and interaction have significant moderation. Effects on the relationship between ease of use and intention to reuse.

3. Research (Rahmayanti \& Wandebori, 2016) results in increasing awareness, companies can embrace the challenges and become market leaders in their fields. Future research might consider testing its effect online, repurchase intentions on other platforms such as social media and not other types of E-commerce businesses.

\section{Methodology}

Research Subject: This study uses marketing management, the object under study consists of two variables: variable $X$ and variable $Y$. The study was conducted to analyze the effect of e-service quality on the intention to reuse the purchase of airline tickets for traveloka users, Tiket.com and Booking.com on FPIPS UPI students. The object of research which is the dependent variable $(Y)$ is the intention to reuse and independent variable $(X)$, namely e-service quality consisting of availability (X1), security (X2), personalization (X3), reliability (X4) and fulfillment (X5).

The type of research used is descriptive (figure 1 and figure 2) and verification (using multiple regression analysis technique) with the method used explanatory survey and cross sectional method. The sample in this study were 300 people, namely traveloka users, Tiket.com and Booking.com on FPIPS UPI students. The population in this study is Traveloka online travel user, Tiket.com and Booking.com from FPIPS UPI Bandung, amounting to 852 people in 2018. Therefore, a sample of 300 respondents will be drawn for this study based on the Slovin formula.

The sampling technique used in this study is a sample random sampling technique and to obtain a proportional sample, the Proportional Stratified Random Sampling technique is used, the analysis technique used is multiple regression and independent sample T-Test to determine the differences in each object.

\section{RESULTS AND DISCUSSION}

Based on the results of data processing, the following findings were obtained:

a. Overview of E-Service Quality on Traveloka online travel agent users, Tiket.com and Booking.com 
INTERNATIONAL JOURNAL OF ACADEMIC RESEARCH IN BUSINESS AND SOCIAL SCIENCES

Vol. 9, No. 3, March, 2019, E-ISSN: 222 2-6990 @ 2019 HRMARS

Table 1

Recapitulation of Respondents Response Results against E-Service Quality

\begin{tabular}{|c|c|c|c|c|c|}
\hline No & Sub Variables & Total Score & $\begin{array}{l}\text { Number } \\
\text { Items }\end{array}$ & of Average Score & $\%$ \\
\hline 1 & Availability & 3612 & 3 & 1204 & 20,1 \\
\hline 2 & Security & 3555 & 3 & 1185 & 19,8 \\
\hline 3 & Personalization & 2348 & 2 & 1174 & 19,6 \\
\hline 4 & Reliability & 2397 & 2 & 1198,5 & 20,0 \\
\hline \multirow[t]{2}{*}{5} & Fulfillment & 2441 & 2 & 1220,5 & 20,4 \\
\hline & Total & 14353 & 12 & 5982 & 100 \\
\hline
\end{tabular}

Source: Data Processing Results, 2018

Based on the results of these calculations it is known that the expected ideal score is 18,000 with a total score of 14,353 . This shows that the score of respondents' responses to e-service quality for students of Traveloka UPI FPIPS, Tiket.com and Booking.com can be categorized as high. The following is the position of the continuum of the e-service quality line presented in Figure 1:

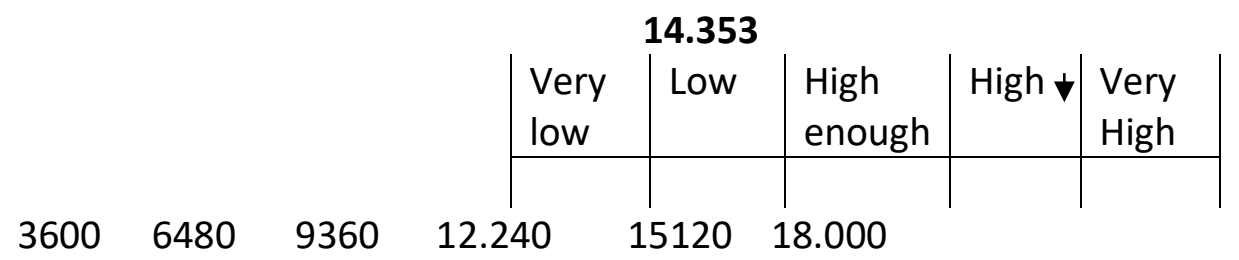

Figure 1

Variable E-Service Quality in the Continuous Line

The data processing results in Figure 1 explain that ideally the continuum value of the respondent's recapitulation results in assessing e-service quality in the UPI FPIPS students using Traveloka, Tiket.com and Booking.com gets a score of 14,353 from the total 12 questions. It can be concluded that the respondents' assessment of e-service quality variables which consist of availability, security, personalization, reliability and fulfillment when viewed in the category in the continuum line are in the high category. This is because all assessments for each dimension are considered to have good performance.

b. Overview of Intention to reuse on Traveloka online travel agent users, Tiket.com and Booking.com

Table 2

Recapitulation of Respondents' Response Results

\begin{tabular}{llllll}
\hline No & Sub Variables & Total Score & $\begin{array}{l}\text { Number } \\
\text { Items }\end{array}$ & of & Average Score \\
\hline 1 & Intention to reuse & 3664 & 3 & 1221,3 & 100 \\
\hline & Total & 3664 & 3 & 1221,3 & 100
\end{tabular}

Source: Data Processing Results, 2018

Based on the results of these calculations it is known that the expected ideal score is 4500 with a total score of 3664 . This shows that the score of respondents' responses to the intention to 
INTERNATIONAL JOURNAL OF ACADEMIC RESEARCH IN BUSINESS AND SOCIAL SCIENCES

Vol. 9, No. 3, March, 2019, E-ISSN: 222 2-6990 @ 2019 HRMARS

reuse Traveloka users, Tiket.com and Booking.com can be categorized as high. The following is the position of the repurchase intention continuum line presented in Figure 2:

3664

900

\begin{tabular}{|l|l|l|l|l|} 
Very Low & Lqw & $\begin{array}{l}\text { High } \\
\text { enough }\end{array}$ & High & Very High \\
\hline & $\checkmark$ & & &
\end{tabular}

\section{Figure 2}

\section{Intention to reusevariable in the Continuous Line}

The data processing results in Figure 2 explain that ideally the continuum value of the respondents' recapitulation results in assessing the intention to reuse Traveloka users, Tiket.com and Booking.com gets a score of 3664 from the number of 3 question items. It can be concluded that the respondents' assessment of the intention to reuse variable, when viewed in the category in the continuum line is in the high category. This is because all assessments for each dimension are considered to have good performance.

C. Effect of E-Service Quality on Intention to reuse

Based on the results of the partial significance test that has been explained previously, then we get 3 results of multiple linear regression equations to influence the e-service quality on the intention to reuse. The details can be stated as follows:

1. Overall 3 OTAs (Traveloka, Tiket.com and Booking.com)

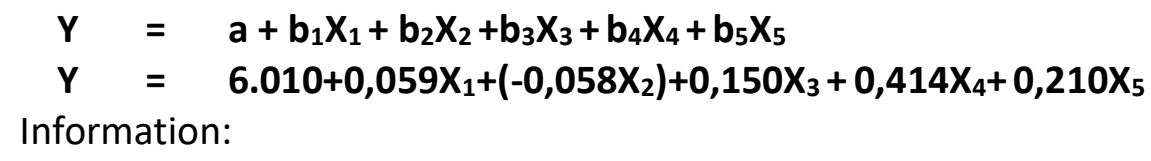

The analysis results show a constant value of 6.010 means that if $X 3, X 4$, and $X 5$ are ignored then the intention to reuse is 6.010 . The coefficient of $X 3$ is 0.150 , meaning that for each increase in one personalization value unit, the value of intention to reuse will increase by $6.010+0.150$, which is 6.160. The $X 4$ coefficient of 0.414 means that for each increase in the value of reliability increases the value of intention to reuse is $6.010+0.414$ which is 6.424 . The last calculation for the X5 coefficient is 0.210 meaning that for each increase in the fulfillment value increases the value of intention to reuse is $6.010+0.210$ which is 6.220 .

2. Traveloka

$$
\begin{aligned}
& Y=a+b_{1} X_{1}+b_{2} X_{2}+b_{3} X_{3}+b_{4} X_{4}+b_{5} X_{5} \\
& Y=6.222+0,050 X_{1}+\left(-0,080 X_{2}\right)+0,212 X_{3}+0,423 X_{4}+0,168 X_{5}
\end{aligned}
$$




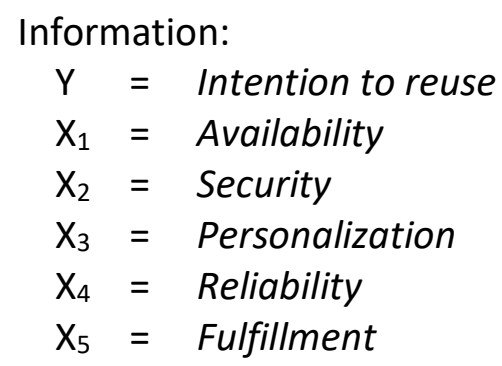

The results of the analysis show a constant value of 6.222 means that if $X 4$ is ignored then the level of intention to reuse is 6.222 . The $X 4$ coefficient of 0.423 means that for each increase in one unit of reliability value will increase the value of intention to reuse by $6.222+0.423$ which is 6.645 .

3. Tiket.com

$$
\begin{aligned}
& Y=a+b_{1} X_{1}+b_{2} X_{2}+b_{3} X_{3}+b_{4} X_{4}+b_{5} X_{5} \\
& Y=5.665+0,225 X_{1}+\left(-0,169 X_{2}\right)+0,118 X_{3}+0,396 X_{4}+0,183 X_{5}
\end{aligned}
$$

Keterangan:

$\mathrm{Y}=$ Intention to reuse

$\mathrm{X}_{1}=$ Availability

$\mathrm{X}_{2}=$ Security

$\mathrm{X}_{3}=$ Personalization

$\mathrm{X}_{4}=$ Reliability

$\mathrm{X}_{5}=$ Fulfillment

The results of the analysis show a constant value of 5.665 means that if $X 1, X 4$ is ignored then the level of intention to reuse is 5.665 . The coefficient of $X 1$ is 0.225 , meaning that for each increase in one value availability unit, the value of intention to reuse will increase by $5.665+0.225$, which is 5.890. The $X 4$ coefficient of 0.396 means that for each increase in the value of reliability increases the value of intention to reuse is $5.665+0.396$ which is 6.061 .

4. Booking.com

$$
\begin{aligned}
& Y=a+b_{1} X_{1}+b_{2} X_{2}+b_{3} X_{3}+b_{4} X_{4}+b_{5} X_{5} \\
& Y=8.480+\left(-0,088 X_{1}\right)+0,179 X_{2}+\left(-0,102 X_{3}\right)+\left(-0,067 X_{4}\right)+0,505 X_{5}
\end{aligned}
$$

Information:

$$
\begin{aligned}
& Y_{1}=\text { Intention to reuse } \\
& X_{1}=\text { Availability } \\
& X_{2}=\text { Security } \\
& X_{3}=\text { Personalization } \\
& X_{4}=\text { Reliability } \\
& X_{5}=\text { Fulfillment }
\end{aligned}
$$

The analysis results show a constant value of 8.480 meaning that if $X 5$ is ignored then the intention to reuse level is 8.480 . The coefficient of $X 5$ is 0.505 meaning that for each increase in one unit of fulfillment value will increase the value of intention to reuse by $8.480+0.505$, which is equal to 8.985 .

D. Comparative analysis uses the Independent Sample T-Test 
INTERNATIONAL JOURNAL OF ACADEMIC RESEARCH IN BUSINESS AND SOCIAL SCIENCES

Vol. 9, No. 3, March, 2019, E-ISSN: 222 2-6990 @ 2019 HRMARS

\begin{tabular}{|c|c|c|c|c|c|c|c|c|}
\hline \multirow{3}{*}{ Dimension } & \multicolumn{6}{|c|}{ Group (Online Travel Agent) } & \multirow{3}{*}{$\mathbf{P}$} & \multirow{3}{*}{ Information } \\
\hline & \multicolumn{2}{|c|}{ Traveloka } & \multicolumn{2}{|c|}{ Tiket.com } & \multicolumn{2}{|c|}{ Booking.com } & & \\
\hline & $\mathbf{x}$ & Sb & $\mathbf{x}$ & Sb & $\mathbf{x}$ & Sb & & \\
\hline $\mathrm{X} 1$ & 13,16 & 1,41 & 11,56 & 1,42 & 10,71 & 1,55 & 0,000 & Different \\
\hline $\mathrm{X} 2$ & 12,61 & 1,44 & 11,28 & 1,64 & 11,26 & 1,39 & 0,937 & No Different \\
\hline $\mathrm{X3}$ & 8,33 & 1,11 & 7,38 & 1.25 & 7,53 & 1,55 & 0,503 & No Different \\
\hline $\mathrm{X} 4$ & 8,70 & 0.97 & 7,03 & 1,30 & 8,04 & 1,18 & 0,000 & Different \\
\hline $\mathrm{X} 5$ & 8,66 & 1,09 & 7,46 & 1,39 & 8,13 & 1,15 & 0,001 & Different \\
\hline
\end{tabular}

Information:

$\begin{aligned} \mathrm{X} & =\text { Average } \\ \mathrm{Sb} & =\text { Simpang Baku } \\ & =\text { There are differences in e- } \\ & \text { service quality } \\ = & \text { There is no difference in e- } \\ & \text { service quality }\end{aligned}$

From Table 4.39 it can be seen that after a different test, in each of the 5 dimensions of e-service quality, there were differences in scores between Traveloka, Tiket.com and Booking.com users, including on availability dimensions, reliability dimensions and on fulfillment dimension

\section{Conclusion}

Based on the results of research that has been done using multiple regression both descriptively and verificatively between e-service quality on the intention to reuse on UPI FPIPS students of Traveloka, Tiket.com and Booking.com users, the following conclusions can be drawn from the research :

1. Based on the responses of respondents regarding the implementation of Traveloka, Tiket.com and Booking.com e-service quality, which consists of availability, security, personalizationz reliability and fulfillment have high criteria. Overall students of UPI FPIPS who use Traveloka, Tiket.com and Booking.com have a good assessment of e-service quality. Personalization, reliability and fulfillment sub-variables are dimensions that get the highest rating from UPI FPIPS students, Traveloka users, Tiket.com and Booking.com. This is because personalization, reliability and fulfillment contained in e-service quality are important because attention, consistency and accuracy can increase user satisfaction and even lead to repeated use of the website. The lowest value is the availability and security performance, because the security and readiness when accessing the website has become an obligation for the quality of a website. So that users assess both aspects are normal.

2. Intention to reuse which is the tendency or desire of the perpetrator to use a technology. The act of using a technology in a person can be predicted from the attitude of attention to certain technologies, for example the desire to add another application to support a technology or have the motivation to persuade others to use a technology. In accordance with Sun \& Ju's opinion, seeing about one's intentions has a significant influence in determining one's actions. 
3. Based on the hypothesis shows that e-service quality has a positive influence on the intention to reuse on Traveloka, Tiket.com and Booking.com are in line with previous research conducted by Chun \& Kwak.

A. Suggestions

Based on the results of research conducted, the authors recommend the following:

1. Effect of e-service quality is proven to affect the intention to reuse, but of course in this case there is still a shortage, especially in one of the e-service quality dimensions, namely availability and security that have low values compared to other dimensions. Availability is completeness or how available the online site is and security is freedom from danger, risk, or doubt. This gives rise to the convenience of customers to exchange information and conduct financial transactions online in response to positive expectations of consumers regarding online company behavior. The recommendations suggested by researchers to the company are to increase the level of readiness, speed in accessing and security and privacy protection.

2. Based on the results of the intention to reuse the Traveloka, Tiket.com and Booking which is lowest ratings on the item question "will always try to purchase flight tickets on the OTA website", therefore the author gives advice to the online travel agent to provide more new features that can make it easier and faster to use the website when ordering other than that with the addition of attractive promotions and the accuracy of promotional promises.

3. Perception guest on e-service quality of the intention to reuse can generally be rated higher, but to maintain and even increase the use to use the OTA website Traveloka, Tiket.com and Booking.com must aggressively improve the quality of the website to be more superior in compete with other OTAs.

As the material on further research on Traveloka, Tiket.com and Booking.com, may appoint another theory marketing strategy to increase the reuse to create and deliver value to the user so that the value received mengakibat user performs reuse. Therefore, these other findings are expected to be an input for the development and progress for Traveloka, Tiket.com and Booking.com in the future.

\section{References}

Adapa, S., \& Ray, C. (2013). Factors Affecting Consumers' Continued Use Of Internet Banking: Empirical Evidence From Australia. Australasian Journal of Information Systems, 18.

Adiwibowo, R. S., Widodo, P., \& Santosa, I. (2015). Correlations Between Public Appreciation of Historical Building and Intention to Visit Heritage Building Reused as Retail Store. Procedia Social and Behavioral Sciences, 184(August 2014), 357-364. https://doi.org/10.1016/j.sbspro.2015.05.103

Akbar, A. A., \& Djatmiko, T. (2016). Pengaruh E-Service Quality Terhadap E-Customer Satisfaction Dan E-Customer Loyalty Pada Lazada.Co.Id. In e-Proceeding of Management (Vol. 3, pp. 142-150).

Asadpoor, S., \& Abolfazli, A. (2017). Effect of Electronic Service Quality on Customer Satisfaction and Loyalty Saderat Bank' s Customers. Ijssl, 5(4), 407-411. https://doi.org/10.17354/ijssl/2017/56

Chun, C. \& Kwak, D. (2016). The Effect of SNS Tourism Information Service Quality on the Intension of Reuse: with a Focus on the Moderating Effect of Reliability and Interaction. International Journal of Software Engineering and Its Applications. 10. 177-188. 10.14257/ijseia.2016.10.10.17. 
INTERNATIONAL JOURNAL OF ACADEMIC RESEARCH IN BUSINESS AND SOCIAL SCIENCES

Vol. 9, No. 3, March, 2019, E-ISSN: 222 2-6990 ¿ 2019 HRMARS

Laurent, F. (2016). Pengaruh E-Service Quality Terhadap Loyalitas Pelanggan Go-Jek Melalui Kepuasan Pelanggan. AGORA, 4(2), 95-100.

Lee, G., \& Lin, H. (2005). Customer perceptions of e-service quality in online shopping. International Journal of Retail \& Distribution Management, 33(2), 161-176. https://doi.org/10.1108/09590550510581485

Lim, W. M. (2014). Antecedents and consequences of e-shopping : an integrated model. Internet Research, 25, No 2, 184-217. https://doi.org/10.1108/IntR-11-2013-0247

Madlberger, M., \& Matook, S. (2017). Theorizing E-Commerce Business Models : On the Impact of Partially and Fully Supported Transaction Phases on Customer Satisfaction and Loyalty. Australasian Journal of Information Systems, 21, 1-25.

Pogorelova, E. V, Yakhneeva, I. V, \& Anna, N. (2016). Marketing Mix for E-commerce. International Journal Of Environmental \& Science Education, 11(14), 6744-6759.

Putri, R. D. H., \& Susanta, H. (n.d.). Faktor-Faktor Yang Mempengaruhi Loyalitas Konsumen Pada Bisnis E-Commerce (Studi Kasus Konsumen Traveloka Pada Mahasiswa Universitas Diponegoro Semarang).

Rahmayanti, A., \& Wandebori, H. (2016). The Effects of E-service Quality on Customer Online Repurchase Intention Towards E-commerce Marketplace C2C in Indonesia. In The 7 Smart Collaboration for Business in Technology and Information Industries (Vol. 2016, pp. 35-40).

Sativa, A., Rahayu, S., \& Astuti, T. (2016). Analisis Pengaruh E-Trust dan E-Service Quality terhadap ELoyalty dengan E-Satisfaction sebagai Variabel Intervening ( Studi pada Pengguna E-Commerce C2C Tokopedia ). DIPONEGORO JOURNAL OF MANAGEMENT, 5, 1-10.

Sun, S., \& Ju, T. (2005). A Study on the Factors Influencing the Intention of Reusing an eCommerce Website. In Americas Conference on Information Systems.

Wu, C., Wu, C., \& Pu, C. (2016). Factors affecting reuse intention of mobile value- added services : A statistical examination. Journal of Statistics and Management Systems ISSN:, 510(May). https://doi.org/10.1080/09720510.2014.1001604 